\title{
Unusual complication associated with a subconjunctival injection of Soframycin
}

\author{
A. M. HAMILTON \\ Wellcome Lecturer in Ophthalmology, Institute of Ophthalmology, University of London
}

\section{Case report}

An I I-day-old infant with bilateral buphthalmos was admitted to Moorfields Eye Hospital. Examination under general anaesthesia showed that the corneal diamter was I I $\mathrm{mm}$. in both eyes. The intraocular pressure (Schiötz) was $40 \mathrm{~mm}$. $\mathrm{Hg}$ in the right eye and 45 $\mathrm{mm}$. $\mathrm{Hg}$ in the left. At this time small yellow scaly plaques were noticed lying between the lashes. A culture taken 24 hours previously was sterile. It was decided to proceed with goniotomy and to give prophylactic subconjunctival Soframycin at the end of the operation.

The anterior chamber could not be seen because of corneal oedema so the corneal epithelium was removed. The technique for removal of the epithelium was to touch it with a cotton-wool swab soaked in absolute alcohol; the epithelium was then scraped off with a No. ${ }_{5} \mathrm{D}$ blade on a Bard Parker scalpel. Bilateral goniotomy was performed using separate instrument trollies. A subconjunctival injection of $5^{\circ} \mathrm{mg}$. Soframycin (Framycetin sulphate) was given to each eye.

The Soframycin $500 \mathrm{mg}$. was in powder form and dissolved in $2.5 \mathrm{ml}$. distilled water taken from a fresh ampoule; $0.25 \mathrm{ml}$. of this solution was injected subconjunctivally and after each injection the lids were closed. A final examination of each eye was made and both corneae were found to be opaque (Figs I and 2). The corneae were examined with the slit on the operating microscope and, although it was difficult to see through the opacity, one had the impression that it was confined to the superficial stroma. There was no alteration in the intraocular pressure.

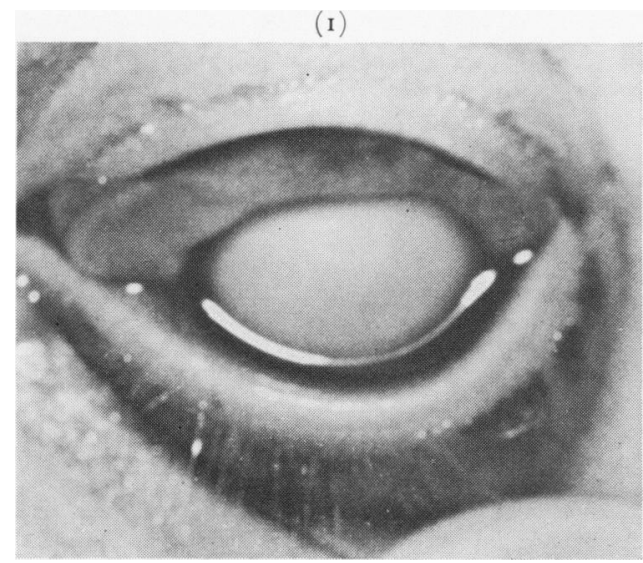

FIG. I Right eye after injection of Soframycin



FIG. 2 Left eye after injection of Soframycin 
The infant was returned to the ward and one hour later both corneae had cleared.

\section{Discussion}

Experimenting with the remainder of the solution of Soframycin and absolute alcohol, it was found that when a few drops of the two were mixed the solution went cloudy white. It was assumed, therefore, that some of the absolute alcohol used to remove the epithelium had remained in the corneal stroma and Bowman's membrane and that it had caused the Soframycin, which had regurgitated from the conjunctival injection site, to be precipitated.

\section{Summary}

The cornea of each eye became temporarily opaque after the injection of Soframycin, following bilateral goniotomy, absolute alcohol having been used to remove the corneal epithelium.

I should like to thank Mr. Redmond J. H. Smith for permission to write up this case and Mr. K. S. Semhi for the photographs. 